\title{
Let's get a two-sided platform started:
}

\section{Tactics to solve the Chicken and Egg Paradox}

\author{
Daniel Trabucchi, PhD \\ School of Management - Politecnico di Milano \\ daniel.trabucchi@polimi.it
}

\section{Abstract}

Two-sided platforms are becoming more and more relevant in the modern economy, with leading examples like Airbnb or Uber. These companies can leverage several opportunities, which are intrinsic in their nature, but they also need to face severe challenges before reaching a critical mass and a mature stage. One of the greatest challenges is represented by the chicken and egg paradox, which refers to the need of the platform provider to convince both sides to join the platform even if it is worthless since the other side is not there. Previous studies provided examples of possible strategies to address it, but there is a lack of operational tactics that practitioners may use to direct tackle the challenges. Through the analysis of 16 case studies based on primary sources, this study presents seven tactics, then clusters in three groups. They are discussed according to previous literature drawing reflections on the characteristics of the two-sided platform and their business model implications.

This is the post-print version of the paper published on the Journal of Business Ecosystems, please cite as

Trabucchi, D., 2020. “Let's get a two-sided platform started: Tactics to solve the Chicken and Egg Paradox", Journal of Business Ecosystems, 1(1), 63-77. 


\section{Introduction}

We live in a tough era for traditional, established companies (Downes and Nunes, 2014). Start-ups may appear out of nowhere - with none of the resources traditionally considered essential for survival - and get relevant market share competing in a brand-new business model (Choudary et al., 2016; Libert et al., 2016; Magistretti et al., 2019), often disrupting established companies as a "collateral damage" (Downes and Nunes, 2013): it is a platform revolution.

The concept of 'platform' evolved significantly towards the decades in the management worlds, moving from product platforms to innovation platforms, and then transactional platforms (Cusumano et al., 2019). This revolution is now led by these transactional platforms that aim to reduce market frictions while enabling two (or even multiple) groups of customers to find themselves, in other words matchmaking various "sides" of the market (Evans and Schmalansee, 2016).

These platforms, studied in the academic literature as Two-Sided Platforms, are defined as an innovative business model that aims to connect people, organizations and resources in an interactive ecosystem where value is created and exchanged (Choudary et al., 2016).

Investors seem to appreciate this emerging model, as the great number of platforms among the Unicorns can show (Trabucchi, Talenti, and Buganza, 2019; Urbinati et al., 2019). Users - whatever it means in these cases - seem to enjoy them as well, as the numbers on their market diffusion can easily show (Libert et al., 2016).

Uber and Airbnb are probably the two leading flags of this revolution, with their multi-billion evaluation and millions of customers around the worlds. They are not alone; there are dozens of successful examples that surround the success of this model, such as Coursera, Deliveroo, YouTube, Spotify, Etsy, and many more. Nevertheless, there are hundreds, probably thousands of companies which are trying to replicate this effective business model without reaching the minimum dimension 
to operate. This is due to the greatest challenge they need to face: they are worthless without both the sides of customers on board, which is famous as the "Chicken and egg" paradox (Caillaud and Julien, 2003).

This research aims to explore this paradox, which represents one of the fundamental characteristics of this kind of businesses, taking and operative and tactical perspective. In other words, the goal of the paper is to identify concrete managerial actions that the platform providers may take to try to overcome the chicken and egg paradox.

\section{Theoretical background}

This research is grounded in the literature on two-sided platform's. The first section deals with the definition and the main characteristics of two-sided platforms. The second section focuses on the chicken and egg paradox.

\section{Definition and main characteristics}

Two-Sided platforms find their roots in the economic literature, where Rochet and Tirole (2003) defined the concept of Two-Sided Markets as "[those markets] in which one or several platforms enable interactions between end-users and try to get the two (or multiple) sides "on board" by appropriately charging each side" (Rochet and Tirole 2006; p. 645).

One of the first examples is the credit card system, where the two sides are cardholders (the demand side) and the merchants (the supply side), which are got together through companies like Mastercard or Visa (e.g., Rysman, 2009).

The chance to have (at least) two groups of customers is only the first necessary conditions to be a two-sided market (Evans, 2003). Indeed, these businesses are characterized by the existence of cross-side network externalities (Katz and Shapiro, 1985). In other words, the value of the service provided by the platform provider depends - for the first side (e.g., cardholders) - by the number of players on the second side (e.g., merchants) and vice-versa. 
After a first phase - in which these businesses have been studied mainly for their pricing dynamics on the two sides (Parker and Van Alstyne, 2005) - scholars realized that "two-sideness" is not necessarily a "market-characteristics" and that it may be and operational choice, moving to the wider concept of Two-Sided Platforms (Hagiu and Wright, 2015)

Over the years, two-sided platforms have been studied from various standpoints. First of all, there are very different types of businesses that may be considered two-sided platforms. A first difference lies between transactional and non-transactional platforms (Filistrucchi et al., 2014). The first enables a direct transaction between the sides, while the ladder exploits the value of the first side through the second, for example through advertising or data exploitations strategies (Trabucchi et al., 2017).

Focusing on transactional platforms there may still a huge heterogeneity. Tauscher and Laudien (2018), focusing on marketplaces, which represent a typical example of transactional two-sided platforms, highlight various variables to classify different platforms. Among the others, they show the chance to have products or service platforms, digital or offline platforms and so on. Interestingly, they show how the demand and the supply side may be represented by very different kinds of players, enabling different kinds of relationships (e.g., C2C, B2C, B2B).

Two-sided platforms have been considered peculiar kinds of resource configurations which lead to new kinds of value creation and capturing (Amit and Han, 2017), often relying to pre-existing technological architectures which are reconfigured to enable new services (Hein et al., 2019). Several opportunities have been highlighted, such as the chance to often rely on idle capacity (e.g., Constantiou et al., 2017; Trabucchi, Muzellec and Ronteau, 2019), or the chance to (usually) scale rapidly relying on a zero-marginal cost structure (Rifkin, 2014; Libert et al., 2016), even though various phases in terms of platform growth can be highlighted (Kim and Yoo, 2019) and in certain situations may emerge a long tail effect (Tauscher, 2019). Moreover, two-sided platforms can 
represent the starting point for more complex businesses, leading to multi-sided platforms with multiple revenue sources (Trabucchi and Buganza, 2019).

Nevertheless, behind great opportunities, severe challenges need to be overcome to have the completely flourished platform (Zhu and lansiti, 2019). Getting on board two groups of customers means being able to offer a meaningful service to both of them, which has severe implications in terms of value proposition design (Muzellec et al., 2015). On top of this, the two groups need to be on board at the very same time, otherwise, the platform is worthless (Caillaud and Julien, 2003). This is known as the chicken and egg paradox, which is the focus of the next section.

\section{Chicken-and-egg paradox}

How can I convince merchants to accept a new credit card? I need to show them that a lot of people own it. But how can I convince people to own a new credit card if not telling them that they can use it in several shops? This very simple example represents the basic concept behind the chicken and egg paradox: the platform provider in transactional two-sided platforms acts as a matchmaker and the system is worthless without the two sides on board. Caillaud and Julien (2003) presented the chicken and egg paradox in one of the seminal papers in the field, but it still represents one of the greatest challenges for all the platform providers that try to set up a two-sided platform (Evans and Schmalansee, 2016; Choudary et al., 2016; Cusumano et al., 2019).

Over the years, scholars provided some guidelines to help companies in facing this challenge. Evans and Schmalansee (2016) presented three main strategies: Two-Steps, Zig-Zag and Commitment Community. A two-step approach aims to get one of the two sides on board first, using it to convince the second one to join. A Zig-Zag strategy, on the contrary, aims at pushing participation on both strategies at the same time. A commitment strategy is related to those cases in which one of the two sides needs to invest in the platform before joining it, as in the case of game consoles. Aside these three strategies, a couple of operational tactics are proposed, such as self-supply (when the 
platform providers act as the supply side in the initial phases), the chance to have marquee customers (having specific customers on one side that may have a relevant impact on the system) or the chance to "make'em believe" or "shaping expectations" (which means convince one group that the other would join when they join).

Stummer and colleagues (2018) built on them to provide a wider picture of the various alternatives. They propose six different strategies: i) Single Target Group (to reduce the scope and starting "small", for example from a city or an industry), ii) Platform staging (to develop a one-side service to evolve later in a two-sided platform), iii) Subsidizing (to get on board one side easily since the service is free, while the other side pays), iv) Platform envelopment (to build a platform on an existing platform or network), v) Exclusivity agreement (to have a dedicated contract on one side that guarantee a safe access to the other side) and vi) Side-switching (to enable customers to be on both sides at the same time).

Other contributions suggest which side should be subsidized, relying on the elasticity of the demand to the price in a cross-side perspective (Parker and Van Alstyne, 2005), or suggest a life-cycle approach from a marketing perspective (Muzellec et al., 2015).

These strategies may help the platform provider in understanding where to start from (e.g., TwoSteps, Zig Zag, Single Target Group) or they may highlight peculiar characteristics of the field (e.g., Commitment community). Otherwise, they may help the platform providers in crafting an idea that may overcome the paradox more easily (e.g., Side-switching, Platform staging) or to avoid going alone (e.g., Platform envelopment; Exclusivity agreement). Nevertheless, they lack in offering a concrete help for those companies that highlighted the market frictions to be reduced (Evans and Schmalansee, 2016) and want to bring the two sides on board. Therefore, this research aims to explore how companies can overcome the chicken and egg paradox at the operational level. In 
particular, it aims to highlight which are possible operational tactics that platform providers may implement to get on board the two sides.

\section{Research Design}

The research design is going to be introduced through two sections. The first one deal with the empirical setting used to pursue the research and the sampling procedure. The second one focuses on the data gathering and data analysis phases.

\section{Empirical setting and sampling procedure}

Due to the exploratory nature of this research a case study approach has been used. In particular, the study is based on a multiple-case study approach taking an inductive perspective to explore this emerging phenomenon (Gioia et al., 2013).

The mobile app industry has been selected as a proper empirical setting, since the intrinsic characteristics of mobile apps are letting emerge a great number of two-sided platforms and has been used in previous studies (e.g., Trabucchi et al., 2017; Trabucchi and Buganza, 2019). The relevance of the mobile app industry is still growing, having forecasts of revenues of 188.99 billion US dollars in 2020, an increase from the 69.7 billion number in 2015 (Statista, 2016). Furthermore, recent research points out mobile apps as the common channel through which companies may enable matching between the two sides (Täuscher and Laudien, 2018). In order to provide an exhaustive answer to this kind of question - focusing on a process dimension in the very early days of the platform development - primary sources are fundamental.

The study relied on a convenience sampling approach using both theoretical and literal replication to increase the validity of the study. The necessary conditions to be considered for the inclusion in the sample are as follows: i) the existence of two groups of customers linked by cross-side network externalities, ii) the existence of a platform provider that enables the link between the two sides, and iii) the existence of a service or product transaction directly enabled by the platform between 
the sides, which indicate at being a Transactional Two-Sided Platform (Evans, 2003; Rochet and Tirole, 2003; Filistrucchi et al., 2014). The theoretical replication logic relies upon the different kinds of players that can constitute the sides of a two-sided platform, which are consumers or businesses (Täuscher and Laudien, 2018). Distinguishing between "demand" and "supply" sides, there are four possible configurations (the first letter represents the demand side, while the latter represents the supply side): C2C, C2B, B2C and B2B. Furthermore, a literal replication logic has been applied, to have multiple cases within the same theoretical condition. The chance to use both theoretical and literal replications aims to increase the external validity of the research (Yin, 2013), reducing the biases of the convenience sampling. 16 companies are part of the final sample of the research, they are summarized in Table 1.

\section{Data gathering and data analysis}

Data collection lasted more than two years, from July 2016 to September 2018. For all the cases, one of the founders or one of the first employees of the companies have been interviewed. Respondents were selected according to their ability to have a longitudinal view of the evolution of the platform, with a clear view on the very early phases. The interview protocol was based on two main parts, starting with an overview of the company and its business model (e.g., the vision, main players involved, revenues model), moving to the chicken and egg paradox (e.g., how they faced it from a strategic perspective, how they brought on board the first side, how they brought on board the second side).

Data was collected through face to face or telephone semi-structured interviews in order to have the space for emerging issues and fresh insights coming from the respondent (Mason, 2002). For each case a single interview has been done, coherently with the narrow focus of this research, nevertheless some of the respondents have been furthered contacted for additional details. Secondary documents, (e.g., press releases, magazine articles, official websites) have been used 
the internal validity of the study (Yin, 2013).

\begin{tabular}{|c|c|c|c|c|c|}
\hline & $\begin{array}{l}\text { Demand } \\
\text { Side }\end{array}$ & Supply Side & Type & Description & Respondent \\
\hline A & Brands & $\begin{array}{l}\text { Photographers by } \\
\text { passion }\end{array}$ & $\mathrm{B} 2 \mathrm{C}$ & $\begin{array}{l}\text { It aims to link bands searching for micro- } \\
\text { influencing and amateur photographers } \\
\text { that get paid for their photos. }\end{array}$ & Co-Founder \\
\hline B & Brands & People & $\mathrm{B} 2 \mathrm{C}$ & $\begin{array}{l}\text { It aims to link brands willing to receive } \\
\text { mystery shopping-like activities and people } \\
\text { willing to perform them. }\end{array}$ & Co-Founder \\
\hline C & End users & Service providers & C2B & $\begin{array}{l}\text { It aims to offer a remote ques management } \\
\text { system. }\end{array}$ & Co-Founder \\
\hline D & Families & Babysitters & $\mathrm{C} 2 \mathrm{C}$ & It aims to match families and babysitters. & Co-Founder \\
\hline $\mathbf{E}$ & End users & Structures & $\mathrm{C} 2 \mathrm{~B}$ & $\begin{array}{l}\text { It aims to link potential customers with } \\
\text { merchants through discounts and coupons. }\end{array}$ & Co-Founder \\
\hline $\mathbf{F}$ & Companies & Students & $\mathrm{B} 2 \mathrm{C}$ & $\begin{array}{l}\text { It aims to link young professional (still } \\
\text { students) with small companies that search } \\
\text { for small professional jobs. }\end{array}$ & Co-Founder \\
\hline G & End users & Professionals & $\mathrm{C} 2 \mathrm{~B}$ & $\begin{array}{l}\text { It aims to link people searching for a } \\
\text { professional with professionals searching } \\
\text { for jobs. }\end{array}$ & Co-Founder \\
\hline $\mathbf{I}$ & End users & Merchants & $\mathrm{C} 2 \mathrm{~B}$ & $\begin{array}{l}\text { It aims to link buyers and sellers through a } \\
\text { new mobile payment system. }\end{array}$ & $\begin{array}{l}\text { Head of } \\
\text { Marketing }\end{array}$ \\
\hline J & $\begin{array}{l}\text { Young } \\
\text { students }\end{array}$ & Companies & $\mathrm{C} 2 \mathrm{~B}$ & $\begin{array}{l}\text { It aims to link bands searching for micro- } \\
\text { influencing and amateur photographers } \\
\text { that get paid for their photos. }\end{array}$ & Co-Founder \\
\hline $\mathbf{K}$ & End users & Bathhouses & $\mathrm{C} 2 \mathrm{~B}$ & $\begin{array}{l}\text { It aims to link people searching for a place } \\
\text { on a private beach with bathhouses }\end{array}$ & Co-Founder \\
\hline $\mathbf{L}$ & End users & Washers & $\mathrm{C} 2 \mathrm{C}$ & $\begin{array}{l}\text { It aims to link busy people that need to } \\
\text { wash their cars with on demand washers. }\end{array}$ & Co-Founder \\
\hline M & Buyers & Sellers & $\mathrm{C} 2 \mathrm{C}$ & $\begin{array}{l}\text { It aims to link people searching for a place } \\
\text { to buy or rent and people that wish to rent } \\
\text { or sell a place. }\end{array}$ & Co-Founder \\
\hline $\mathbf{N}$ & Travellers & Renters & $\mathrm{C} 2 \mathrm{C}$ & $\begin{array}{l}\text { It aims to links students searching and } \\
\text { offering rooms and apartments for short } \\
\text { periods. }\end{array}$ & $\begin{array}{l}\text { Business } \\
\text { Development } \\
\text { Manager }\end{array}$ \\
\hline 0 & Companies & Business Schools & B2B & $\begin{array}{l}\text { It aims to link head hunters with the new } \\
\text { graduates from business school through } \\
\text { their career services. }\end{array}$ & Co-Founder \\
\hline $\mathbf{P}$ & End users & Cookers & $\mathrm{C} 2 \mathrm{C}$ & $\begin{array}{l}\text { It aims to link foreign travellers with home } \\
\text { cookers }\end{array}$ & Co-Founder \\
\hline $\mathbf{Q}$ & End users & Drivers & $\mathrm{C} 2 \mathrm{C}$ & $\begin{array}{l}\text { It aims to link people that cannot driver } \\
\text { their own car with on demand drivers }\end{array}$ & Co-Founder \\
\hline
\end{tabular}


To analyze the rich body of data collected, an inductive and iterative process has been adopted (Miles and Huberman, 1984; Corbin and Struss, 2008), hence building and refining theory from the case studies data (Eisenhardt, 1989). In particular, the gathered documents and transcribed interviews have been analyzed through three main phases: reading, coding, and interpreting (Saldaña, 2015), Relying on the suggestions from Corbin and Strauss (2008), an open coding process based on the identification of key sentences from the documents. For each interview, key sentences regarding how the platform provider faced the chicken and egg paradox have been highlighted. The quote have been sorted into first order categories, highlighting the specific tactics that are going to be described in the Results. Finally, through axial coding, the first order categories have been grouped together - relying on previous literature to identify commonalities and difference from a conceptual perspective - giving birth to the three classes of tactics presented in the discussion.

\section{Results}

The qualitative results are going to be presented through two main steps. This section begins with a summary of the within case analysis. Due to the number of the cases, the within case analysis is going to be reported through a table summarizing the main findings for each case. Then, a crosscase analysis is going to be presented, proposing a classification of the techniques emerged through the interviews.

\section{Within case analysis}

For each case various information have been searched, studied and structured: i) information regarding the users on the demand and on the supply side ii) the type of transactional platform ( $\mathrm{C} 2 \mathrm{C}, \mathrm{B} 2 \mathrm{C}, \mathrm{C} 2 \mathrm{~B}$ or $\mathrm{B} 2 \mathrm{~B})$ iii) the strategy applied according to the three defined by Evans and Schmalansee (2016) and iv) a key quote from the demand and the supply side with a label referring 
to the tactics that will be described in details in the following subsections. Appendix 1 , at the end of the paper, summarizes all these information for the 16 cases.

\section{Cross-case analysis}

The analysis of the cases led to the identification of seven different tactics to solve the chicken and egg paradox. These seven tactics are briefly described in the following of the section.

\section{Leveraging an Existing network}

One of the two sides may be engaged in the platform relying on previous relationships that the platform provider had. This is means that, the chance to involve an existing community of players that were enjoying a similar service, solve the chicken and egg paradox bringing on board a significant number of players with a single action. A necessary condition for this tactic is the chance to have a pre-engaged community - which is common for services that are evolving towards twosided platforms.

The strategy has been used in two cases, in both of them the target were professionals that were belonging to close communities.

Door 2 Door

This tactic is based on the idea that the platform provider, probably through the usage of an initial network of salespersons, tries to engage players on one of the two sides one by one, proposing the service and explaining the value proposition.

This very simple tactics have been widely used in the sample, with 9 companies using it. Interestingly a common element emerges for all of them: it has been used to involve a business-side, both large corporations or small companies (such as restaurants or bars). 


\section{Direct Marketing}

The chance to rely on traditional marketing activities as a way to solve the chicken and egg paradox on one of the two sides has been largely used in the sample, even though with different peculiarities. In some cases, companies created marketing events in specific cities with a specific target, to expose the vast majority of selected people to the existence of the new service. Other companies pushed it a bit furthered, going for social media advertising, still having the chance to target the campaign, but moving to a different order of magnitude in terms of exposition. Finally, some companies used more classic advertisement means such as press to create a genera awareness around the service while trying to get on board customers on one side. Eight companies used this technique to involve at least one of the two sides, interestingly in the vast majority of cases the targeted side was a consumer-side, in a smaller percentage of cases they were targeting professional of small businesses.

\section{Bandwagon effects from the other side}

There are cases in which the tactics to bring on board one side...is to not take direct action towards that side, but use the other one to create externalities. In other words, the chance to have one of the two sides I considered enough to have the other one on board as well. This happened in particular in two cases based on a C2B structure, where the B side - adopting the platform - became the direct promoter of the service for the other side. The chance to have business or small businesses already on board, while offering a service directly related to the physical place - let the platform to not take a direct action to bring the C-side on board. 
In one specific case, the chance to involve a key player (specifically universities, the common ground that links the two sides) acted as the key tactics to involve both sides on the platform provider. It is difficult to draw general conclusions based on a single observation, but it may still be interesting to note how both the sides are represented by consumers and how potential customers on both sides share a single physical space for their ordinary activities, which enabled this tactic.

\section{Simulating one side}

A peculiar tactic emerged from two cases. In order to avoid solving the chicken and egg paradox, the platform provider pretended to have on board a side that was not there, simulating its existence. In other words, the platform provider also acted as the demand side to enhance the proliferation of the service on the other side, build the system and involve the real players only in a second stage through other tactics. Interestingly, both cases refer to a Businesses on the demand side, pretending to have companies asking for the other side, which would have been difficult to involve in the first place.

\section{Contarct side}

Similar to the previous tactic, one case let emerge this last observation, working on the supply side. Instead of involving professionals searching for people that believe in the value proposition of the entire system, the platform decided to hire a couple of people to let the platform take off, solving artificially the chicken and egg paradox.

\section{Discussion}

The data gathered during this exploratory research are going to be discussed according to previous research in the field. In particular, the section is going to be divided into two main sub-sections: first, a general comment based on how the case studies fit previous studies is going to be presented, then three main clusters of tactics are going to be discussed. 
Evans and Schmalansee (2016) highlighted three main strategies to manage the chicken and egg paradox, namely the Two-Steps strategy, the ZigZag and the Commitment community. Interestingly, the case studies of this research rely mainly on the first one with a common characteristic: they start from the supply side. Only two cases rely on the Zigzag strategy, aiming to bring on board both customers at the same time. Both cases involve consumers players on both sides.

The type of players involved on the two sides deserves more attention. Previous studies (e.g., Tauscher and Laudien, 2018) highlighted how two-sided platforms might have various configurations involving both C-players and B-players. Digging in the analysis of the cases, a greater heterogeneity emerges. In particular, there are companies dealing with individuals that share characteristics of C-players but are actually joining the platform to perform their ordinary work, these players have been labeled as "Professionals". Similarly, there are several B-players involved in the study, but they are significantly different. In some cases, the target for the platform providers are large corporations that decide to join a service through the platform, in other cases the players targeted by the platform providers are small shops, restaurants and other local activities that decide to join this type of businesses through completely different decision making processes, they have been labeled as "Small Businesses". This is enlarging the previous classifications of players involved in two-sided platforms.

On top of this rather general considerations on how previous classifications fit the studied cases, the research let emerge seven different operational tactics that can be implemented to solve the chicken and egg paradox. Even though they are different at the operational level, they may be grouped in three clusters according to the approach they have. The three clusters are: "Proper twosided tactics", "One player for the other(s)" and "Stepping through a one-sided planform", which are summarized in Figure 1. 


\begin{tabular}{|c|c|c|c|c|c|c|c|}
\hline & \multicolumn{3}{|c|}{$\begin{array}{c}\text { Proper two-sided } \\
\text { tactics }\end{array}$} & \multicolumn{2}{|c|}{$\begin{array}{l}\text { One player for } \\
\text { the other(s) }\end{array}$} & \multicolumn{2}{|c|}{$\begin{array}{l}\text { Stepping through a } \\
\text { one-sided platform }\end{array}$} \\
\hline & $\begin{array}{l}\text { Leveraging an } \\
\text { existing network }\end{array}$ & $\begin{array}{l}\text { Door } 2 \\
\text { Door }\end{array}$ & $\begin{array}{c}\text { Direct } \\
\text { Marketing }\end{array}$ & $\begin{array}{l}\text { Bandwagon effect } \\
\text { from the other side }\end{array}$ & $\begin{array}{l}\text { Involving } \\
\text { Key players }\end{array}$ & $\begin{array}{l}\text { Simulating } \\
\text { one side }\end{array}$ & $\begin{array}{l}\text { Contract } \\
\text { side }\end{array}$ \\
\hline $\begin{array}{l}\text { Type of players } \\
\text { involved }\end{array}$ & Professionals & Businesses & $\begin{array}{c}\text { Mainly } \\
\text { consumers, but } \\
\text { also Professionals }\end{array}$ & Consumers & Consumers & Businesses & Professionals \\
\hline \multirow[t]{2}{*}{$\begin{array}{l}\text { Type of side } \\
\text { involved }\end{array}$} & Supply side & Both sides & $\begin{array}{l}\text { Both demand } \\
\text { and supply }\end{array}$ & Demand side & Both sides & Demand side & Supply side \\
\hline & $\begin{array}{r}\text { - Potentially } \\
\text { - Most general } \\
\text { in terms }\end{array}$ & $\begin{array}{l}\text { seful both for } \\
\text { Zigzag strateg } \\
\text { t tactics, with } \\
\text { f players or s }\end{array}$ & $\begin{array}{l}\text { Two-steps and } \\
\text { es } \\
\text { low peculiarities } \\
\text { les involved }\end{array}$ & $\begin{array}{l}\text { - The first is clear } \\
\text { the secon } \\
\text { - Seem to be dire } \\
\text { the type of } \\
\text { needing a physi }\end{array}$ & $\begin{array}{l}\text { y Two-steps, } \\
\text { Zigzag } \\
\text { tly related to } \\
\text { latforms, } \\
\text { al dimension }\end{array}$ & \multicolumn{2}{|c|}{ 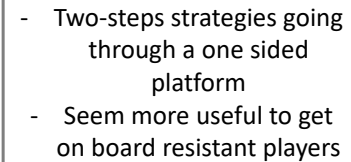 } \\
\hline
\end{tabular}

Figure 1 - Three clusters of tactics to solve the chicken and egg paradox

The first cluster - "Proper two-sided tactics" - group together the tactics "Leveraging an existing network", "Door 2 Door" and "Direct Marketing" (with all its nuances, from events to social media and other means). These can be considered the most direct tactics to solve the chicken and egg paradox trying to convince the potential customers to join the platforms and are also the closer to previously mentioned strategies (e.g., Evans and Schmalansee, 2016; Stummer et al., 2018). They are potentially useful in different settings - both Two-Steps and ZigZag - and appear to be quite wide in terms of players involved or type of service (physical or digital) (Tauscher and Laudien, 2018).

The other two clusters offer greater insights. The second one, "One player for the other(s)", groups the tactics "Bandwagon effect from the other side" and "Involving key players". These two tactics are indirect ways to solve the paradox, indeed on of the two sides join the platform thanks to the effect of someone else (being the other side, or a third player able to influence both). These tactics may sound like the operationalization of the marquee customers to ignite the platform (Evans and Schmalansee, 2016), even though in this case the focus is or on an entire side or on a player that is able to gather both sides. These two alternatives are particularly interesting if we analyze the impact in terms of value flows. Indeed, the involvement of specific players directly generate the interest 
around the platform for other players, basically leveraging cross-side or cross-players network externalities (Katz and Shapiro, 1985; Rochet and Tirole, 2003) to solve the chicken and egg paradox, rather than as a key characteristic of the working platform. It seems that a physical dimension and a C-player as a target (Tauscher and Laudien, 2018) is needed to implement these tactics.

The last cluster, "Stepping though a one-sided platform", groups "Simulating one side" and "Contract side". These two tactics are suggesting a completely different perspective on how to solve the chicken and egg paradox: to quit the two-sided logic, going for a classic "one-sided" business. These tactics are therefore suggesting a lifecycle management approach to the development of the platform, suggesting how in different stages different business models and value propositions may be suitable (Muzellec et al., 2015). At the same time, they are suggesting that the evolutionary perspective on two-sided platforms, adding sides throughout the lifecycle, may start even before the chance to grow into multi-sided platforms (Trabucchi and Buganza, 2019), having the second side as an evolutionary step. These considerations regarding the lifecycle approach two the platform management are coherent with the recent consideration on the diffusion of disrupting services (Downes and Nunes, 2014). Indeed, it seems that the traditional diffusion curve (Rogers, 2010) is being often replaced by a shar-fin curve, that suggest a very fast diffusion process (Downes and Nunes, 2013). These findings are suggesting approaches that consider a continuous business model evolution that include different groups of customers over time.

In other words, these two tactics avoid the chicken and egg paradox faking one of the two sides (or hiring it or pretending it exists, having the platform provider that acts also as a supply side). Interestingly, both of theme emerged as tactics to involve businesses or professionals. In particular, the two cases that implemented the "Simulating one side" tactic are involving in this way a business side on the demand side, which is a very peculiar situation. In other words, the one-side phase is used to test and validate the operational model, while showing the feasibility and the potential 
value of the system, that is offered only in a second phase to real companies - once the supply side (consumers) are already on board. This is coherent with agile approaches to business model development (Ghezzi and Cavallo, 2018).

\section{Conclusion and Implications}

This paper aims to explore one of the fundamental challenges for two-sided platforms: how to solve the chicken and egg paradox. Instead of taking a strategic perspective, as previous research (e.g. Evans and Schmalansee, 2016; Stummer et al., 2018), it aims at highlighting operations tactics that platform providers can implement to get on board the two sides.

\section{Theoretical and managerial contributions}

From a theoretical perspective it move the discussion on the paradox from a strategic to an operational issue, while linking it with the topics of lifecycle of the platform (Muzellec et al., 2015) and the evolutionary perspective of the platform (Trabucchi and Buganza, 2019), highlighting the potential role of network externalities in solving the paradox and the business model dimension. On top of that, the study acts as a confirmatory studies on previous findings, searching for the actual implementation of previously identified strategies to ignite the platform (Evans and Schamalansee, 2016), while completing previous classifications of the type of platforms and the type of players involved (Tauscher and Laudien, 2018).

From a managerial perspective, the study may help practitioners in dealing with the complex challenge of letting start a two-sided platform, having the chance to go through a list of potential operational tactics having an overview on how they have been used before. On top of that, the characterization of the three clusters let emerge possible directions that diverge from a classic approach in which the platform provider tries to directly bring on board the two sides.

\section{Directions for future studies}


The research is not free of limitations, being based on a convenience sample that tries to leverage the replication to reduce biases. Moreover, it is based on an exploratory analysis of the tactics, without providing further details on the opportunities and challenges in implementing them. Both the limitations may be addressed by future research, checking for the existence of other tactics, while testing the opportunities and challenges for all of them. Indeed, this study may open various directions for future studies. Recent research claims how emerging technologies (e.g., Al, blockchain) may increase the relevance of digital platforms (e.g., Hein et al., 2019), future studies may study if and how the chance to rely on infrastructure like the blockchain may interfere with the chicken and egg paradox. Similarly, the diffusion of these business models is challenging theories that emerged in the digital world, such as the long tail (Tauscher, 2019), it may be interesting to understand if platforms that act as followers in a given industry may experience different dynamics in solving the paradox.

\section{References}

Amit, R., \& Han, X. (2017). Value creation through novel resource configurations in a digitally enabled world. Strategic Entrepreneurship Journal,

Caillaud, B., \& Jullien, B. (2003). Chicken \& egg: Competition among intermediation service providers. RAND Journal of Economics, , 309-328.

Choudary, S. P., Parker, G. G., \& Van Alstyne, M. W. (2016). Platform revolution: How networked markets are transforming the economyand how to make them work for you WW Norton \& Company.

Constantiou, I., Marton, A., \& Tuunainen, V. K. (2017). Four models of sharing economy platforms. MIS Quarterly Executive, 16(4)

Corbin, J., \& Strauss, A. (2008). Basics of qualitative research. 2008.

Cusumano, M. A., Yoffie, D. B., \& Gawer, A. (2019). The business of platforms: Strategy in the age of digital competition, innovation, and power HarperCollins Publishers.

Downes, L., \& Nunes, P. (2014). Big bang disruption: Strategy in the age of devastating innovation Penguin.

Downes, L., \& Nunes, P. (2013). Big bang disruption. Harvard Business Review, 44-56. 
Eisenhardt, K. M. (1989). Building theories from case study research. Academy of Management Review, 14(4), 532-550.

Evans, D. S. (2003). The antitrust economics of multi-sided platform markets. Yale Journal on Regulation, 20(2), 325-381.

Evans, D. S., \& Schmalensee, R. (2016). Matchmakers: The new economics of multisided platforms Harvard Business Review Press.

Filistrucchi, L., Geradin, D., Van Damme, E., \& Affeldt, P. (2014). Market definition in two-sided markets: Theory and practice. Journal of Competition Law and Economics, 10(2), 293-339.

Ghezzi, A., \& Cavallo, A. (2018). Agile business model innovation in digital entrepreneurship: Lean startup approaches. Journal of Business Research,

Gioia, D. A., Corley, K. G., \& Hamilton, A. L. (2013). Seeking qualitative rigor in inductive research: Notes on the gioia methodology. Organizational Research Methods, 16(1), 15-31.

Hagiu, A., \& Wright, J. (2015). Multi-sided platforms. International Journal of Industrial Organization, 43, 162-174.

Hein, A., Schreieck, M., Wiesche, M., Böhm, M., \& Krcmar, H. (2019). The emergence of native multisided platforms and their influence on incumbents. Electronic Markets, 1-17.

Katz, M. L., \& Shapiro, C. (1985). Network externalities, competition, and compatibility. The American Economic Review, 75(3), 424-440.

Kim, J., \& Yoo, J. (2019). Platform Growth Model: The Four Stages of Growth Model. Sustainability, 11(20), 5562.

Libert, B., Beck, M., \& Wind, J. (2016). The network imperative: How to survive and grow in the age of digital business models Harvard Business Press Review.

Magistretti, S., Dell'Era, C., \& Petruzzelli, A. M. (2019). How intelligent is Watson? Enabling digital transformation through artificial intelligence. Business Horizons, 62(6), 819-829.

Mason, J. (2002). Qualitative researching 2nd edition sage.

Miles, M. B., \& Huberman, A. M. (1984). Drawing valid meaning from qualitative data: Toward a shared craft. Educational Researcher, 13(5), 20-30.

Muzellec, L., Ronteau, S., \& Lambkin, M. (2015). Two-sided internet platforms: A business model lifecycle perspective. Industrial Marketing Management, 45, 139-150.

Parker, G. G., \& Van Alstyne, M. W. (2005). Two-sided network effects: A theory of information product design. Management Science, 51(10), 1494-1504. doi:10.1287/mnsc.1050.0400 
Rifkin, J. (2014). The zero marginal cost society: The internet of things, the collaborative commons, and the eclipse of capitalism St. Martin's Press.

Rochet, J. -., \& Tirole, J. (2003). Platform competition in two-sided markets. Journal of the European Economic Association, 1(4), 990-1029. doi:10.1162/154247603322493212

Rochet, J. -., \& Tirole, J. (2006). Two-sided markets: A progress report. RAND Journal of Economics, 37(3), 645-667.

Rysman, M. (2009). The economics of two-sided markets. The Journal of Economic Perspectives, 23(3), 125-143.

Saldaña, J. (2015). The coding manual for qualitative researchers Sage.

Stummer, C., Kundisch, D., \& Decker, R. (2018). Platform launch strategies. Business \& Information Systems Engineering, , 1-7.

Täuscher, K., \& Laudien, S. M. (2018). Understanding platform business models: A mixed methods study of marketplaces. European Management Journal, 36(3), 319-329. doi:10.1016/j.emj.2017.06.005

Täuscher, K. (2019). Uncertainty kills the long tail: demand concentration in peer-to-peer marketplaces. Electronic Markets, 1-12.

Trabucchi, D., \& Buganza, T. (2019). Fostering digital platform innovation: From two to multi-sided platforms. Creativity and Innovation Management,

Trabucchi, D., Muzellec, L., \& Ronteau, S. (2019). Sharing economy: Seeing through the fog. Internet Research,

Trabucchi, D., Talenti, L., \& Buganza, T. (2019). How do big bang disruptors look like? A business model perspective. Technological Forecasting and Social Change, 141, 330-340.

Trabucchi, D., Buganza, T., \& Pellizzoni, E. (2017). Give away your digital services: Leveraging big data to capture value. Research-Technology Management, 60(2), 43-52. doi:10.1080/08956308.2017.1276390

Urbinati, A., Chiaroni, D., Chiesa, V., \& Frattini, F. (2019). The Role of Business Model Design in the Diffusion of Innovations: An Analysis of a Sample of Unicorn-Tech Companies. International Journal of Innovation and Technology Management, 16(01), 1950011.

Yin, R. K. (2013). Case study research: Design and methods Sage publications.

Zhu, F., \& lansiti, M. (2019). Why Some Platforms Thrive and Others Don't. Harvard Business Review, 97(1): 118-125. 


\section{Appendix}

\begin{tabular}{|c|c|c|c|c|c|c|c|c|c|c|}
\hline & $\begin{array}{l}\frac{0}{0} \\
\frac{0}{n} \\
\frac{O}{C} \\
\frac{1}{0} \\
\frac{E}{0} \\
0\end{array}$ & $\begin{array}{l}\frac{0}{0} \\
\frac{0}{n} \\
\frac{2}{2} \\
\frac{0}{7}\end{array}$ & $\stackrel{\Perp}{\stackrel{2}{2}}$ & $\begin{array}{l}\frac{1}{0} \\
\frac{0}{n} \\
\frac{0}{2} \\
\frac{C}{0} \\
\frac{1}{2} \\
0\end{array}$ & $\begin{array}{l}\frac{0}{0} \\
\frac{0}{n} \\
\frac{2}{0} \\
\frac{2}{3} \\
\text { v }\end{array}$ & 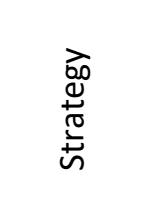 & Quotes Demand site & $\begin{array}{c}\text { Tactics } \\
\text { Demand side }\end{array}$ & Quotes Supply side & $\begin{array}{c}\text { Tactics } \\
\text { Supply side }\end{array}$ \\
\hline A & $\begin{array}{l}\frac{n}{0} \\
\frac{1}{0} \\
\frac{0}{\infty}\end{array}$ & 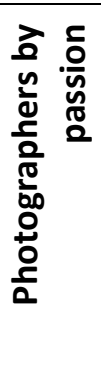 & $\underset{\text { U }}{\text { U }}$ & $\infty$ & $u$ & 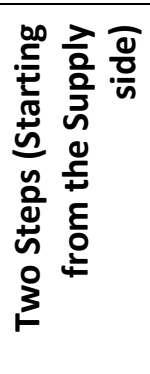 & $\begin{array}{l}\text { "They showed them the power of a } \\
\text { 100.000+ users' community } \\
\text { through the intermediation of a } \\
\text { marketing agency." }\end{array}$ & Door 2 Door & $\begin{array}{l}\text { "We launched campaigns every day, of } \\
\text { course we did not have brands, so we } \\
\text { invented them, sunset photos, benches } \\
\text { photos, photos with friends, we saw that this } \\
\text { helps to: engage users and to improve the } \\
\text { visibility of the app that it's not a simple } \\
\text { platform for advertisement but something } \\
\text { that supports brands." }\end{array}$ & $\begin{array}{l}\text { Simulating } \\
\text { one side }\end{array}$ \\
\hline B & $\begin{array}{l}\frac{n}{0} \\
\frac{1}{0} \\
\frac{0}{\infty}\end{array}$ & $\frac{\frac{0}{0}}{\frac{0}{0}}$ & $\underset{\text { N }}{\text { U }}$ & $\boldsymbol{\infty}$ & u & 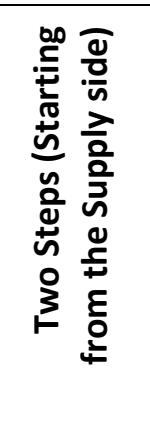 & $\begin{array}{l}\text { "Papers-case studies talking about } \\
\text { the problem that the platform } \\
\text { solves in the case of Findus, } \\
\text { Telecom Italia, and circulate them } \\
\text { among an audience who are } \\
\text { potential clients. This is much more } \\
\text { effective than advs campaign or } \\
\text { trying to get an appointment with } \\
\text { companies using call cold." }\end{array}$ & Door 2 Door & $\begin{array}{l}\text { "publish fake jobs: jobs which had not been } \\
\text { sponsored by any kind of company but had } \\
\text { been direct delivery and self-financing by the } \\
\text { platform. This has served to give birth to the } \\
\text { first users" Then they continuous to get on } \\
\text { board people for the supply side through } \\
\text { Social Media advertising. }\end{array}$ & $\begin{array}{l}\text { Simulating } \\
\text { one side }\end{array}$ \\
\hline
\end{tabular}




\begin{tabular}{|c|c|c|c|c|c|c|c|c|c|c|}
\hline C & 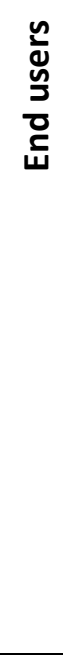 & 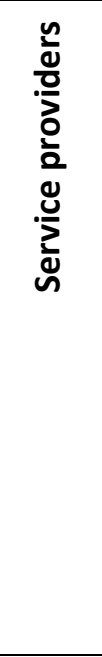 & $\stackrel{\tilde{U}}{~}$ & $u$ & $\infty$ & 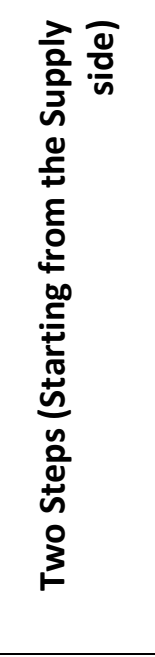 & $\begin{array}{l}\text { "The demand sided got on board } \\
\text { through the direct advertising of } \\
\text { the first supply-side customers." }\end{array}$ & $\begin{array}{l}\text { Bandwagon } \\
\text { effect from } \\
\text { the other } \\
\text { side }\end{array}$ & $\begin{array}{l}\text { "The beginning the key strategy applied was } \\
\text { to validate the idea and the system through } \\
\text { a networking with universities, which tried } \\
\text { the app in the secretarial students to } \\
\text { facilitate queue system". Thus, immediately } \\
\text { they get on board the first users on both } \\
\text { sides. } \\
\text { These validation trials of the platform were } \\
\text { used as "case studies that helped us to close } \\
\text { first contracts with new customers, e.g. in } \\
\text { the first year we closed a sperimental } \\
\text { contract (case study) and in the next one we } \\
\text { closed } 20 \text { contracts even if Italy it's a bit } \\
\text { skeptical country for new technology". }\end{array}$ & Door 2 Door \\
\hline D & 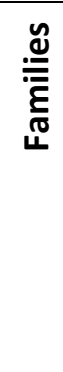 & 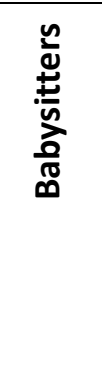 & Ư & $u$ & $a$ & 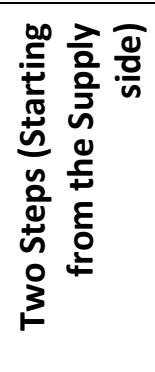 & $\begin{array}{l}\text { "Then, for the 'family side', the best } \\
\text { strategy applied to get on board, } \\
\text { was to implement marketing } \\
\text { campaign, like: 'Are you searching } \\
\text { the right babysitter?' Through also } \\
\text { article on the website we were able } \\
\text { to attract more users that want to } \\
\text { use the service." }\end{array}$ & $\begin{array}{l}\text { Marketing - } \\
\text { Social media }\end{array}$ & $\begin{array}{l}\text { "[We started wit] Private, hidden, invisible } \\
\text { Facebook group, where I was the only } \\
\text { administrator, deciding who could become a } \\
\text { member or not. I started adding all my } \\
\text { friends and every time I received a job offer, I } \\
\text { published it on the Fb page, matching the } \\
\text { demand with the supply." }\end{array}$ & $\begin{array}{l}\text { Leveraging } \\
\text { an existing } \\
\text { network }\end{array}$ \\
\hline $\mathrm{E}$ & 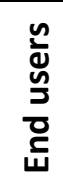 & 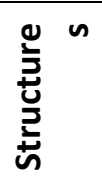 & ปี & u & nै & 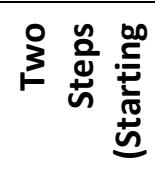 & $\begin{array}{l}\text { "The demand sided got on board } \\
\text { through the direct advertising of } \\
\text { the first supply-side customers." }\end{array}$ & $\begin{array}{l}\text { Bandwagon } \\
\text { effect from } \\
\text { the other } \\
\text { side }\end{array}$ & $\begin{array}{l}\text { "We used mainly agents, already present in } \\
\text { this similar kind of market like Groupon" }\end{array}$ & Door 2 Door \\
\hline $\mathbf{F}$ & 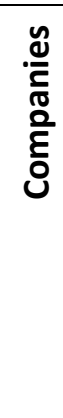 & 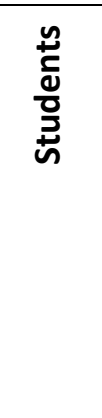 & 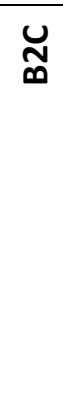 & $\ddot{n}$ & $a$ & 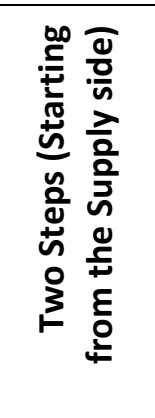 & $\begin{array}{l}\text { "We pursuit a targeting marketing } \\
\text { campaign through digital, physical } \\
\text { channels, events and online- } \\
\text { offline media. Then, we understand } \\
\text { that the most efficient tool was } \\
\text { Facebook, because is the one that } \\
\text { cost less. Moreover, it's easy to } \\
\text { understand if a message was } \\
\text { efficient or not thanks to KPIs" }\end{array}$ & $\begin{array}{l}\text { Marketing - } \\
\text { Social media, } \\
\text { events, press }\end{array}$ & "Direct marketing in universities" & Marketing \\
\hline
\end{tabular}




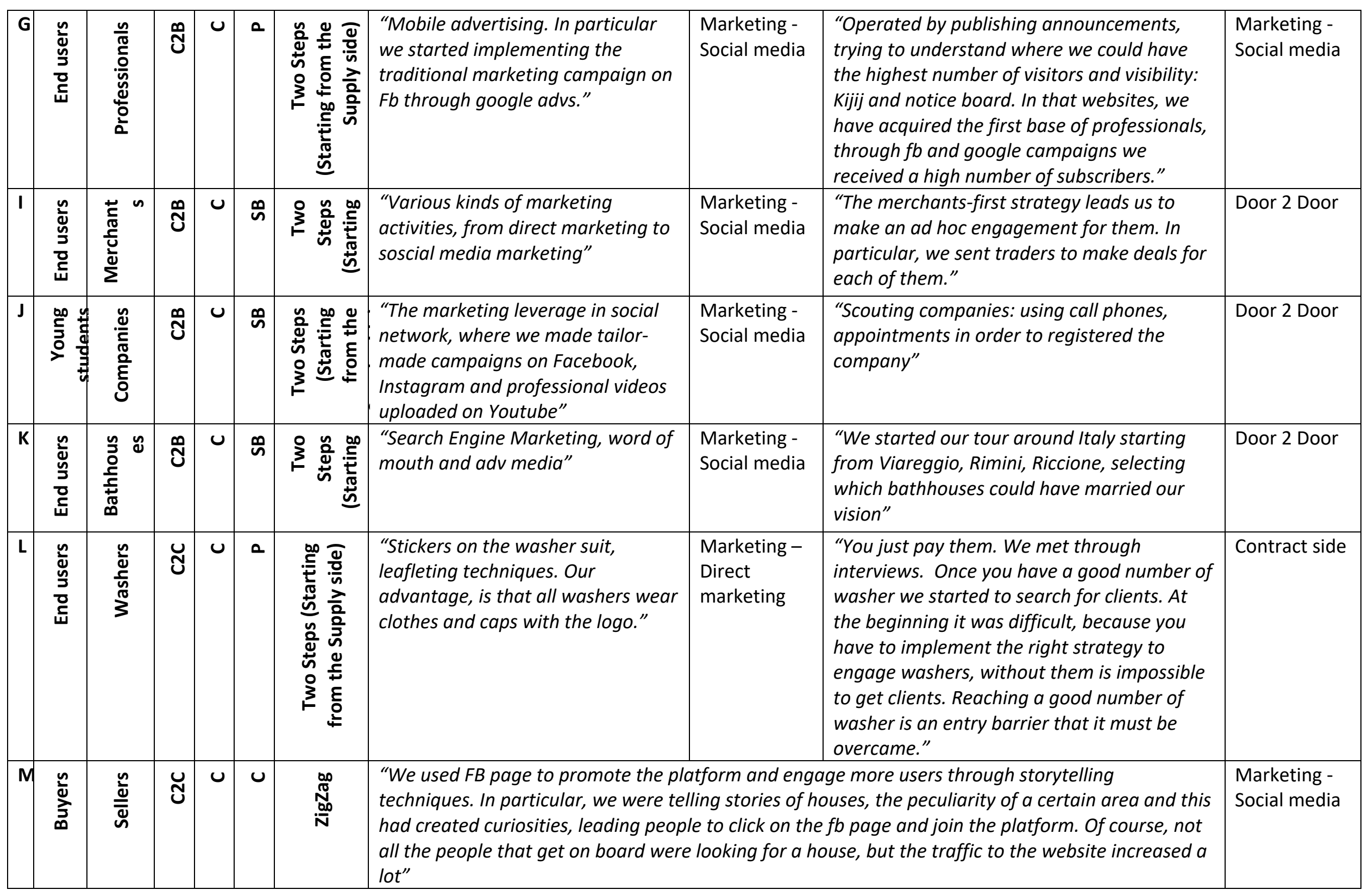




\begin{tabular}{|c|c|c|c|c|c|c|c|c|c|c|}
\hline $\mathbf{N}$ & 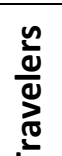 & 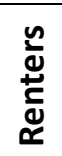 & U্ড & u & u & 离 & $\begin{array}{l}\text { "The service at the beginning was co } \\
\text { offering possibilities for their studen } \\
\text { abroad. This helped the platform to }\end{array}$ & $\begin{array}{l}\text { npletely free a } \\
\text { to rent their } \\
\text { et on board fir }\end{array}$ & $\begin{array}{l}d \text { we made partnership with universities } \\
\text { oms and to find available room when they go } \\
\text { t clients on both side." }\end{array}$ & $\begin{array}{l}\text { Involving a } \\
\text { key player }\end{array}$ \\
\hline $\mathbf{P}$ & 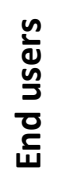 & $\frac{n}{\ddot{\varpi}}$ & Uు & ט & a & 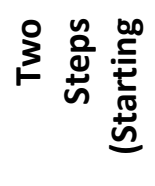 & $\begin{array}{l}\text { "Continued to do traditional } \\
\text { marketing campaign through FB } \\
\text { pages and FB advs" }\end{array}$ & $\begin{array}{l}\text { Marketing - } \\
\text { Social media }\end{array}$ & $\begin{array}{l}\text { "Scouting companies: using call phones, } \\
\text { appointments in order to register the } \\
\text { company" }\end{array}$ & $\begin{array}{l}\text { Leveraging } \\
\text { an existing } \\
\text { network }\end{array}$ \\
\hline $\mathbf{Q}$ & 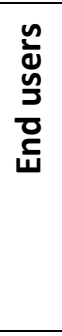 & 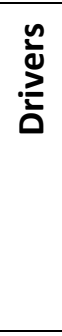 & త্ড & ט & 0 & 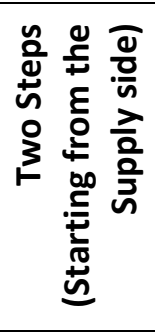 & $\begin{array}{l}\text { "we went online to advertising and } \\
\text { proposing our service with } \\
\text { targeting marketing campaign for } \\
\text { different cities. }\end{array}$ & $\begin{array}{l}\text { Marketing - } \\
\text { Social media }\end{array}$ & $\begin{array}{l}\text { "Search and recruit in advance drivers } \\
\text { through Facebook advs and recruiting } \\
\text { website (Kiji), informing and explaining our } \\
\text { idea in a clear way that this required service } \\
\text { platform will be launched soon. Moreover, } \\
\text { they conducted a face to face interview } \\
\text { recruitment" }\end{array}$ & $\begin{array}{l}\text { Marketing - } \\
\text { Social media }\end{array}$ \\
\hline & & & & & & & $=$ Consumers, $P=$ Profe & & es, B=Businesses & \\
\hline
\end{tabular}

Appendix 1 - Within case analysis

The author would like to thank all the practitioners that have been interviewed and dedicated their time to this research. Moreover, the author would like to acknowledge Luca Gianluigi De Bernardi, who provided a valuable contribution in early stages of this research. 